\title{
STUDY OF PREVALENCE OF DENTAL CARIES AMONG THE POPULATION OF JAGDALPUR, CHHATTISGARH
}

\author{
Raichoor Anil Kumar ${ }^{1}$
}

${ }_{1}^{1}$ Professor and HOD, Maxillofacial Surgery, Department of Dentistry, Lt. BRKM Govt. Medical College, Jagdalpur, Bastar, Chhattisgarh.

\begin{tabular}{l}
\hline ABSTRACT \\
\hline BACKGROUND \\
Dental caries is a major and significant oral health condition that affects about 50 to $60 \%$ of the population in India among oral \\
diseases. Unfortunately in rural areas oral health care is often limited due to lack of perceived need for dental care among the rural \\
population, financial constraints as well as shortage of dental manpower.
\end{tabular}

\section{AIM}

This study aims to determine the prevalence of dental caries among the general population of Jagdalpur and also determine the important factors that could have contributed to the disease.

\section{SETTING AND DESIGN}

Case records of patients who reported to the Department of Dentistry were studied retrospectively. Information about decayed, missed, filled teeth, occupation, oral hygiene techniques as well as dental visits was recorded.

\section{METHODS AND MATERIAL}

Retrospective data of 100 patients who visited the Department of Dentistry was collected from the medical records division. Case sheets having incomplete information or patients who were aged below 5 years and above 75 years were not considered for the study.

\section{STATISTICAL ANALYSIS}

Was done using software SPSS 17.0 version. Chi square test (Descriptive Statistics) was done to test the significance of nonparametric analysis. P values were considered significant at $0.05 \%$ level.

\section{RESULTS}

Of the 100 case records that were examined, dental caries was more prevalent in males than females with asymptomatic significance of both dental caries and missing teeth to be statistically significant. Restored teeth contributed to almost $72.72 \%$ of the population.

\section{CONCLUSION}

The prevalence of dental caries among the rural general population is significantly high. Less frequent dental visits and improper or inadequate brushing technique/methods could have contributed to the high incidence of dental caries. Creating awareness regarding proper oral hygiene methods as well as regular dental checkup is recommended.

\section{KEYWORDS}

Dental Caries, Prevalence, Rural Population.

HOW TO CITE THIS ARTICLE: Kumar RA. Study of prevalence of dental caries among the population of Jagdalpur, Chhattisgarh. J. Evolution Med. Dent. Sci. 2016;5(61):4241-4243, DOI: 10.14260/jemds/2016/967

\section{INTRODUCTION}

Dental caries has been aptly defined as an irreversible microbial disease of the calcified tissues of the teeth, characterized by demineralization of the inorganic portion and destruction of the organic substance of the tooth, which often leads to cavitation (Shafer 1993). ${ }^{1}$ Among the oral diseases, dental caries is a major concern among the rural population and if neglected it leads to pain and spread of infection to the paraoral structures. Various studies regarding

Financial or Other, Competing Interest: None.

Submission 10-07-2016, Peer Review 22-07-2016,

Acceptance 25-07-2016, Published 29-07-2016.

Corresponding Author:

Raichoor Anil Kumar,

Qtr. No. 9, Type V,

LTBRKM Govt. Medical College Campus,

Dimrapal, Jagdalpur-494001,

Chhattisgarh.

E-mail:drrakumar@yahoo.com

DOI: $10.14260 /$ jemds/2016/967 the prevalence of dental caries in India have been published, but have concentrated mostly on school children.2,3,4,5 There is paucity of literature regarding the prevalence of dental caries in the general population, especially in the rural regions which have significant diverse cultures and habits. World Health Organization (WHO) recommends basic oral health surveys in the age groups of 5 years, 12 years, 17-18 years, 35-44 years and 65-74 years. Epidemiological data is not only essential to update about the recent trends of the disease, but also plays a very vital role in the prophylaxis as well as treatment planning.

\section{METHODS}

Retrospective data of 100 patients who visited the Department of Dentistry was collected from MRD (Medical Records Division). Data regarding decayed, missing, filled teeth, occupation, oral hygiene methods and dental visits of every patient was compiled and subjected. Patients whose case records had inadequate data and who were aged less 
than 5 years and above 75 years were not included in the study.

\section{Ethics}

This study involved retrospective collection of data. Ethical Committee approval is not applicable.

\section{Statistical Procedures}

For non-parametric analysis, Chi square test was used. P values were considered statistically significant at $0.05 \%$ level.

\section{RESULTS}

In this study, higher incidence of dental caries was seen at the either end of the age spectrum (Table-1). Males were more affected than females. The prevalence of dental caries and missing teeth was statistically significant at 0.030 and 0.049 values respectively; however, almost $72.72 \%$ of the study population had restored teeth (Tables-2 and 3). Based on the occupation it is seen that professionals had a higher rate of dental caries than students (Table-4). Almost $78.9 \%$ of the subjects had a dental visit due to caries (Table-5).

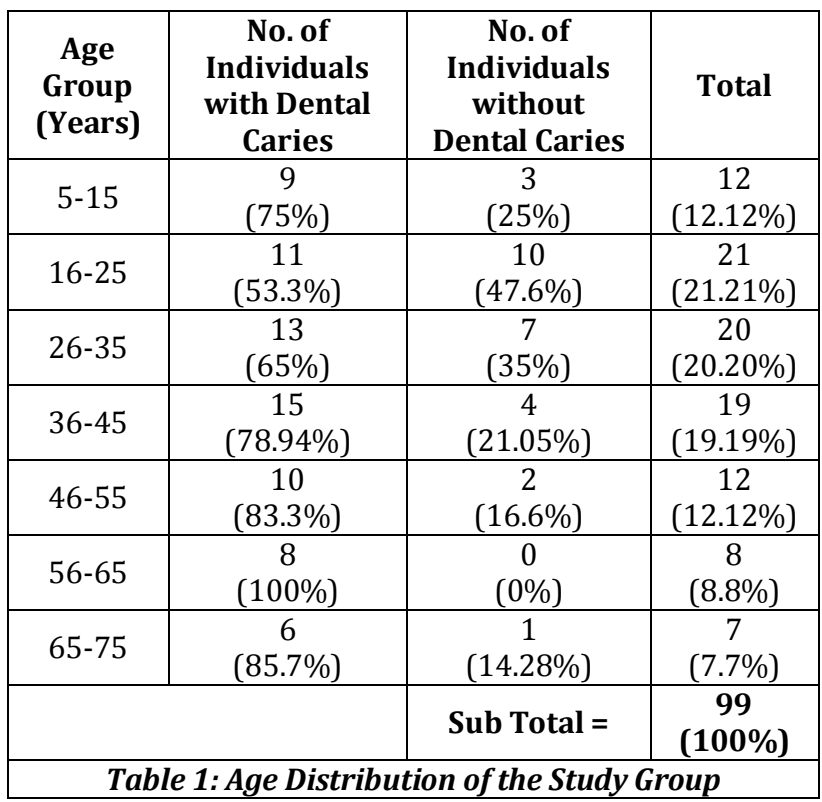

\begin{tabular}{|c|c|c|c|c|c|c|c|c|c|c|c|c|}
\hline \multirow{2}{*}{ Gender } & \multicolumn{4}{|c|}{$\begin{array}{c}\text { Dental } \\
\text { Caries } \\
\end{array}$} & \multirow{2}{*}{$\begin{array}{l}\text { Total } \\
(\%)\end{array}$} & \multirow{2}{*}{$\begin{array}{l}\text { Asymp } \\
\text { Sig }\end{array}$} & \multicolumn{4}{|c|}{$\begin{array}{c}\text { Missing } \\
\text { Teeth }\end{array}$} & \multirow{2}{*}{$\begin{array}{l}\text { Total } \\
(\%)\end{array}$} & \multirow{2}{*}{ Asymp Sig } \\
\hline & Yes (\%) & $\begin{array}{c}\text { Ex- } \\
\text { pected }\end{array}$ & $\begin{array}{l}\text { No. } \\
(\%)\end{array}$ & $\begin{array}{c}\text { Ex- } \\
\text { pected }\end{array}$ & & & Yes (\%) & $\begin{array}{c}\text { Ex- } \\
\text { pected }\end{array}$ & No (\%) & $\begin{array}{c}\text { Ex- } \\
\text { pected }\end{array}$ & & \\
\hline Male & $\begin{array}{c}58 \\
(78.3 \%) \\
\end{array}$ & 53.8 & $\begin{array}{c}16 \\
(21.6 \%) \\
\end{array}$ & 20.2 & $\begin{array}{c}74 \\
(74.7 \%)\end{array}$ & \multirow{3}{*}{$\begin{array}{c}\text { Sig } \\
0.030\end{array}$} & $\begin{array}{c}31 \\
(49.8 \%) \\
\end{array}$ & 26.9 & $\begin{array}{c}43 \\
(58.1 \%)\end{array}$ & 47.1 & $\begin{array}{c}74 \\
(74.7 \%) \\
\end{array}$ & \multirow{3}{*}{ Sig 0.049} \\
\hline Female & $\begin{array}{c}14 \\
(56.0 \%) \\
\end{array}$ & 18.2 & $\begin{array}{c}11 \\
(44.0 \%) \\
\end{array}$ & 6.8 & $\begin{array}{c}25 \\
(25.2 \%) \\
\end{array}$ & & $\begin{array}{c}5 \\
(20 \%) \\
\end{array}$ & 9.1 & $\begin{array}{c}20 \\
(80 \%) \\
\end{array}$ & 15.9 & $\begin{array}{c}25 \\
(25.2 \%) \\
\end{array}$ & \\
\hline Total & $\begin{array}{c}72 \\
(72.7 \%)\end{array}$ & 72.0 & $\begin{array}{c}27 \\
(27.2 \%\end{array}$ & 27.0 & $\begin{array}{c}99 \\
(100 \%)\end{array}$ & & $\begin{array}{c}36 \\
(36.3 \%)\end{array}$ & 36.0 & $\begin{array}{c}63 \\
(63.0 \%)\end{array}$ & 63.0 & $\begin{array}{c}99 \\
(100 \%)\end{array}$ & \\
\hline \multicolumn{7}{|c|}{$\begin{array}{l}\text { Note: } 0 \text { cells }(0.0 \%) \text { have expected count less than } 5 . \\
\text { The minimum expected count is } 6.82 .\end{array}$} & \multicolumn{6}{|c|}{$\begin{array}{c}\text { Note: } 0 \text { cells }(0.0 \%) \text { have expected count less than } 5 . \\
\text { The minimum expected count is } 9.09 .\end{array}$} \\
\hline \multicolumn{13}{|c|}{ Table 2: Prevalence of Dental Caries and Missing Teeth } \\
\hline
\end{tabular}

Asymp = Asymptomatic

Sig $=$ Significance

\begin{tabular}{|c|c|c|c|}
\hline & Yes & No & Total \\
\hline \multirow{2}{*}{ Filled } & 72 & 27 & 99 \\
& $(72.72 \%)$ & $(27.27 \%)$ & $(100 \%)$ \\
\hline \multicolumn{3}{|c|}{ Table 3: Restored/Filled Teeth of } \\
the Study Population \\
\hline
\end{tabular}

\begin{tabular}{|c|c|c|c|}
\hline Occupation & $\begin{array}{c}\text { No. of } \\
\text { Individual } \\
\text { s with } \\
\text { Dental } \\
\text { Caries }\end{array}$ & $\begin{array}{c}\text { No. of } \\
\text { Individua } \\
\text { ls without } \\
\text { Dental } \\
\text { Caries }\end{array}$ & Total \\
\hline Profess & $\begin{array}{c}39 \\
(78 \%)\end{array}$ & $\begin{array}{c}11 \\
(22 \%)\end{array}$ & $\begin{array}{c}50 \\
(50.50 \\
\%)\end{array}$ \\
\hline Students & $\begin{array}{c}17 \\
(58.6 \%)\end{array}$ & $\begin{array}{c}12 \\
(41.37 \%\end{array}$ & $\begin{array}{c}29 \\
(29.29 \\
\%)\end{array}$ \\
\hline Others & $\begin{array}{c}16 \\
(80 \%)\end{array}$ & $\begin{array}{c}4 \\
(20 \%)\end{array}$ & $\begin{array}{c}20 \\
(20.20 \\
\%)\end{array}$ \\
\hline Total & $\begin{array}{c}72 \\
(72.72 \%)\end{array}$ & $\begin{array}{c}27 \\
(27.27 \%)\end{array}$ & $\begin{array}{c}99 \\
(100 \%)\end{array}$ \\
\hline
\end{tabular}

\begin{tabular}{|c|c|c|c|}
\hline & $\begin{array}{c}\text { No. of } \\
\text { Individuals } \\
\text { with Dental } \\
\text { Caries }\end{array}$ & $\begin{array}{c}\text { No. of } \\
\text { Individuals } \\
\text { without Dental } \\
\text { Caries }\end{array}$ & Total \\
\hline $\begin{array}{c}\text { Dental } \\
\text { Visit }\end{array}$ & 60 & 16 & 76 \\
$(78.9 \%)$ & $(21.05 \%)$ & $\begin{array}{c}76.76 \\
\%)\end{array}$ \\
\hline $\begin{array}{c}\text { Brushin } \\
\text { g }\end{array}$ & 69 & 26 & $\begin{array}{c}95 \\
(72.63 \%)\end{array}$ \\
\hline \multicolumn{3}{|c|}{ Table 5: Distribution of Dental Caries in Individuals } \\
Based on their Habits
\end{tabular}

\section{DISCUSSION}

In India approximately $72 \%$ of the population reside in the rural regions. It is very important to establish data regarding the prevalence of dental caries in these areas, so that the quality of life can be improved. In most of the studies conducted in India, there is a lot of variation in the prevalence of dental caries. This may be attributed to different study population, difficult study setting, dietary habits, varied cultural practices, oral hygiene habits and also fluoride content of water. ${ }^{6}$

In this study, we have followed the age group pattern which was recommended by WHO. The prevalence of dental caries in this study almost corroborates with other studies between the age group of 25-55 years. 7,8 Ramachandran K et $\mathrm{al}^{9}$ reported the prevalence of dental caries was $65.9 \%$ in 
children aged 4-6 years and according to National Oral Health survey of India caries prevalence among 5-year-old children was $51.9 \%$. Statistically, in this study for age group between 5-15 years it is 75\% when compared with other age groups. In a study by Shubha PE. 10 Prevalence of dental caries in the age group of 60 years and above was $77.7 \%$. For the similar age group in this study it is $85.7 \%$; however, this value is much higher when compared to the study done by Shah $\mathrm{N}$ and Sundaram KR. ${ }^{11}$ who reported only $64.2 \%$.

When we compare the prevalence of dental caries among the sex distribution of this study population, it was found that males $(74.7 \%)$ had a higher incidence than females $(24.2 \%)$. In the overall population, even though $72.72 \%$ had filled teeth and $78.9 \%$ had a dental visit the prevalence of dental caries and missing teeth were statistically significant. This could be due to lack of awareness towards oral hygiene in general and improper/inadequate use of oral hygiene technique in particular or lack of motivation to have regular dental checkup.

From this study, it can also be inferred that there is little correlation between the literacy rate and oral health care, as almost $78 \%$ of the professionals suffered from dental caries when compared to the other groups.

There are many limitations to this study. As this was a retrospective study, it was difficult to find out the exact cause of missing tooth which could have been due to severe dental caries or due to severe periodontal disease or any other pathology. The other limitation was that the dietary habits of the population were not known, which could have contributed or could have been one of the factors for such a high prevalence rate of dental caries. Lastly, the fluoride content of the water which plays a vital role in dental caries could not be determined due to technical limitations.

\section{CONCLUSION}

The prevalence of dental caries among the rural general population is significantly high. Less frequent dental visits and improper or inadequate brushing technique/methods could have contributed to the high incidence of dental caries. Creating awareness regarding proper oral hygiene methods as well as regular dental checkup is recommended.

\section{ACKNOWLEDGEMENTS}

I would like to sincerely thank Dr. Rama Krishna Ph.D. for his expert opinion on the statistical analysis for this study.

\section{REFERENCES}

1. Rajendran R, Shivapathasundharam B, Raghu AR. Shafer's textbook of oral pathology. Shafer, Hine, Levy eds. $6^{\text {th }}$ ed. Noida, India: Elsevier 2005.

2. Vecher BR. Dental survey of school children in Amritsar. J Indian Dent Assoc 1952;24:2-8.

3. Dutta A. Study on the prevalence of periodontal and dental caries amongst school going children. J Indian Dent Assoc 1965;37:12-5.

4. Sarvanan S, Madivanan I, Subhashini B, et al. Prevalence pattern of dental caries in the primary dentition among school children. Indian J Dent Res 2005;16(4):140-6.

5. Acharya S. Dental caries, its surface susceptibility and dental fluorosis in south India. Int Dent J 2005;55(6):359-64.

6. Hansa K, Basavaraj P, Asish S, et al. Dental caries scenario among 5, 12 and 15- year-old children in Indiaa retrospective analysis. Journal Clinical Diagnostic Research 2015;9(7):ZE1-5.

7. Mahajabeen R, Sudha P, Kulkarni SS, et al. Dental caries prevalence among preschool children of Hubli: Dharwad city. J Indian Soc Pedod Prev Dent 2006;24(1): 19-22.

8. Thomas S, Raja RV, Kutty R, et al. Pattern of caries experience among an elderly population in south India. Int Dent J 1994;44(6):617-22.

9. Ramachandran K, Sujatha S, Murugesan G, et al. Prevalence of dental caries among school going children in Namakkal district: a cross sectional study. J Pharm Bio Allied Sci 2014;6(5):160-1.

10. Shubha EP, Chandana CS. Prevalence of dental caries among Chennai population. J Pharm Sci \& Res 2015;7(10):895-6.

11. Shah N, Sundaram KR. Impact of socio demographic variables oral hygiene practices oral habits and diet on dental caries experience on Indian elderly: a community based study. Gerodontology 2004;21(1):43-50. 